\title{
Lisansüstü öğrencilerinin lisansüstü eğitimi almaya ilişkin görüşleri
}

\author{
Sevilay Aydemir \\ Gazi Üniversitesi, Eğitim Fakültesi, Ankara, Türkiye, sevilayaydemir84@gmail.com \\ Şefika Sümeyye Çam \\ Gazi Üniversitesi, Eğitim Fakültesi, Ankara, Türkiye, sumeyyesubay@gmail.com
}

\begin{abstract}
ÖZ Öğrenciler lisans eğitimini tamamladıktan sonra çeşitli amaç ve beklentilerle gerekli koşulları sağlayıp, bir lisansüstü programa başvururlar. Bu süreçte öğrenciler, alanlarında kendilerini sürekli geliştirmeleri gerektiği, zaman zaman uykusuz, huzursuz, hatta bir süre toplumdan ve yakın çevreden koparak, yoğun araştırmalar ve çalışmalar yapmaktadırlar. Bu çalışmada öğrencilerin daha az çalışmak, daha az düşünüp huzurlu olmak yerine; bu yoğun ve uzun sürece katılmayı neden istedikleri araştırılmıştır. Araştırma sorularına yanıt bulmak için nitel araştırma türlerinden vaka çalışması kullanılmıştır. Çalışma grubunda 10 lisansüstü öğrencisi yer almaktadır. Örneklem, amaçlı örnekleme yöntemlerinden maksimum çeşitlilik örnekleme yöntemi kullanılarak oluşturulmuştur. Veriler, araştırmacılar tarafindan hazırlanan ve beş sorudan oluşan yapılandırılmış görüşme formuyla toplanmıştır. Elde edilen veriler içerik analizi yöntemi ile çözümlenmiştir. Araştırma sonucunda elde edilen bulgulara göre; öğrencilerin çoğu lisansüstü eğitimi akademik kariyer için tercih etmişlerdir. Bu kapsamda kendi alanlarında yetkin ve etkili olmak, toplum içinde saygınlık kazanmak yönünde beklentilerinin oldukları tespit edilmiştir. Ortaya çıkan bulgulara göre bireylerin bilimsel çalışmalara yönlendirilmesine yönelik öneriler ileri sürülmüştür.
\end{abstract}

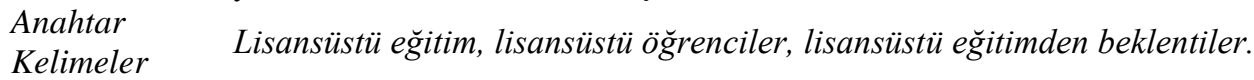

\section{Graduate students views of related taking graduate education}

\footnotetext{
ABSTRACT Students completing undergraduate studies apply to graduate programs by providing necessary conditions with various goals and expectations. In this process, as the students need to develop themselves continuously, they focus on research intensively, become occasionally sleepless, restless and even detached from society and environment. In this research it was investigated why the students want to participate in this intensive and long process instead of being relaxed with less work. The case study, one of qualitative research methods, was used to answer research questions. 10 master and $\mathrm{PhD}$ students are included in the sample. The sample was chosen by maximum variation sampling method, one of the purposive sampling methods. Data was collected with structured interview form consisting of five questions. The data was analyzed by content analysis. According to the findings, most of the students prefer the graduate education for an academic career. Their expectations have been identified as being competent and effective in their areas and gaining respect in the community. Lastly, some recommendations have been proposed for future studies.

Keywords Graduate education, Graduate students, Expectation from graduating education.
} 


\section{EXTENDED SUMMARY}

Some students graduate from college and apply to a master or $\mathrm{PhD}$ education by providing necessary conditions with various goals and expectations. In this process, as the students need to develop themselves continuously, they focus on research intensively, being occasionally sleepless, restless and even detached from society and environment. In this research it was investigated why the students want to participate in this intensive and long process instead of being relaxed with less work.

The purpose of this study is that determining why students have graduate study and what their expectation are about the graduate education. For this purpose, students' views are taken based on 5 questions.

a. What are the graduate student's opinions about functions of graduate education?

b. Which factors have been effect to graduate students in demanding to graduate education?

c. What is the role of graduate education on graduate students' expectations of future goals and what they think about contribution of graduate education?

d. What are the graduate students' opinions about the program which they study on?

e. What are graduated student's expectations towards graduate education?

To find answer of the questions qualitative method was used. The case study, one of qualitative research methods was used in this study. The study was carried out with 10 graduate students which study in 2011-2012 academic year. The sampling group was selected with maximum diversity sampling which is a type of purposive sampling. 4 of $10(40 \%)$ graduate student was PhD students, 6 of $10(60 \%)$ graduate student was master students.

Data were collected using a structured questionnaire prepared by the researchers. Literature on the subject was examined to create interview form and a faculty member from educational administration department gave opinion and made suggestions about the interview form. The interview form consists of 5 open-ended questions. Interviews are carried out face to face with the graduate students and took about twenty minutes. The interview was recorded with the consent of the students then these records are put on paper. Written form was confirmed by the interviewees in terms of accuracy.

Categorical analysis, which is a content analysis method was used to analyze the data. Written data are coded and combined under the sub-themes. Then, the sub-themes were identified under the main themes and relationships between themes were determined. Also, to ensure the reliability of data analysis, the data were coded by expert in the field. This formula was applied to ensure reliability: Reliability $=$ Consensus/ Consensus + Dissidence X 100. Correspondence percentage of coding was calculated as $77 \%$.

Validity in qualitative research, what is the right level of research results and research on the suitability of the general framework; the reliability of research, the results of research to be separate bias and errors.

In this context, the following measures have been taken to improve the reliability and validity of the study;

a. In order to increase the internal validity of the study, participants' statements were made written after the interview. Then revisions of these texts were provided. And the data obtained in the interview process reflect the real situation aimed during the interview. Content analysis data were also revised several times.

b. In order to increase the external validity of the study, the research process are explained in detail.

c. To increase the reliability of the study interior the findings emerging from the content analysis tries to explain without review.

d. In order to increase the reliability of the research the research process is presented in detail. The obtained data encodings are kept by the researcher in case they can be studied again.

Consequently, as to students' views on the function of post-graduate education; tendency of individuals to scientific research, they aim to become qualified individuals and gain different perspectives.

Most of the students demand graduate education to improve themselves. Also, factors such as passion about learning research affect them to have graduate education. The vast majority of students are required to have graduate education to be an academic personal as well. For these reasons, they have some expectations from graduate education. Lastly, the students' expectations about graduate education are being competent and effective in their areas. 
For the benefit of graduate education, education and research need to be adopted by students. In this direction, future studies can be made. For this, a graduate education curriculum should be developed with students ideas. In addition, in order to enjoy this long process, various methods should be used. For example; student-advisor solidarity should be achieved. Students should decide their way of study to improve themselves. 


\section{GİRIŞ}

Bireylerin lisans eğitimi alarak sahip olduğu bilgiler çağın belli bir kısmına cevap verebilecek düzeydedir. Artarak ilerleyen bilgi, gelişen teknoloji ve buna paralel olarak değişen dünyaya bireylerin uyum sağlayabilmesi, değişmelerin ve gelişmelerin öncüsü olabilmesi için; sahip oldukları bilgiyi devamlı güncellemeleri ve öğrenmeye istekli hale gelmeleri gerekmektedir. Dolayısıyla bireylerin sadece lisans eğitimiyle sahip olduğu bilgiyi ömür boyu kullanması olanaksızdır (Karakütük, 2001; Varış, 1972).

Lisans eğitiminden sonra bireyin kendini daha çok geliştirip topluma katkısının artması adına üniversiteler lisansüstü eğitimi gerçekleştirmektedirler. Bilime katkıda bulunmak, teknolojinin ilerlemesini sağlamak, ülkede yaşanan problemlere bilimsel bir bakış açısıyla çözüm üretebilmeyi hedefleyen lisansüstü eğitim ile nitelikli insan gücü oluşturulması esas alınmaktadır (Köksalan, 1999). Lisansüstü eğitim ile topluma katkı sağlayan bilim insanı ve öğretim üyeleri yetiştirilmektedir. Çeşitli alanlarda yetişen bilim insanları ve öğretim üyeleri gelecek nesillerin şekillenmesinde büyük rol oynadıkları için lisansüstü eğitim kalitesinin yüksek psiko-sosyal ve bilimsel yarar sağlayacak şekilde olması gerekir (Karayalçın, 1998).

Bireylerin isteklerini esas alan lisansüstü eğitim ile Türkiye'deki öğretmenlerin \% 7'si eğitim alarak mezun olmuşlardır. Diğer ülkelere bakıldığında ise bu oranın; Avusturya'da \%59, Belçika'da \% 84, Polonya'da \% 94, Slovakya'da \% 96 olduğu görülmektedir (MEB, 2010). Arada oldukça büyük bir fark görülmektedir. Bu oranın ülkemizde de arttırılması adına Milli Eğitim Bakanlığı tarafından da çeşitli uygulamalar ile lisansüstü eğitim programlarına teşvik arttırılmaya çalışılmaktadır. Buna rağmen yeterli düzeyde lisansüstü eğitimin sağlanamaması, mevcutların da yeterli uygulamaları gerçekleştirememeleri bir problem olarak görülmektedir. Bu noktada öncelikle öğrencilerin istek ve beklentilerine yönelik bir eksikliğin söz konusu olduğu düşünülebilir.

Bu problem kapsamında araştırmada lisansüstü eğitim gören öğrencilerin neden lisansüstü eğitim almak istediklerini ve bu eğitimden beklentilerini, onların görüşleri doğrultusunda belirlenmiştir. Bu amaca yönelik şu sorulara cevap aranmıştır;

a. Lisansüstü öğrencilerinin lisansüstü eğitimin işlevine yönelik görüşleri nelerdir?

b. Lisansüstü öğrencilerinin lisansüstü eğitimi talep etmelerinde hangi faktörler etkileyici olmuştur?

c. Lisansüstü öğrencilerinin gelecekle ilgili hedeflerinde aldıkları lisansüstü eğitimin yeri nedir ve öğrenciler lisansüstü eğitimin kendilerine hangi yönde katkılarının olacağını düşünmektedirler?

d. Lisansüstü öğrencilerinin öğrenim görmekte olduğu programla ilgili düşünceleri nelerdir?

e. Lisansüstü öğrencilerinin lisansüstü eğitimden beklentileri nelerdir?

Gömleksiz ve Yıldırım'ın (2013) çalışmalarına göre, lisansüstü öğrencilerinin aldıkları eğitimden beklentileri öncelikle kariyer sahibi olmak, alanlarında kendilerini geliştirmek ve akademik yeterliğe sahip olmaktır. Yapılan bu çalışmada öğrencilerin beklentilerinin kısmen karşılandığı ileri sürülmüştür. Ören, Yılmaz ve Güçlü (2014) de öğretmen adaylarının aynı nedenlerden dolayı lisansüstü eğitim yapmak istediklerini ortaya koymuşlardır. Golde ve Dore (2001) ise doktora öğrencilerinin doktora eğitiminden beklentileri üzerine bir çalışma yapmışlardır. Buna göre öğrencilerin büyük bir çoğunluğunun akademik bir yaşantıya sahip olmak yani akademik kariyer yapmak için bu süreci yaşamak istediklerini belirlemişlerdir. Maddi beklentiler, statü kazanmak ve sosyal yaşantıyı hareketlendirmek gibi isteklerle ise karşılaşılmadığı vurgulanmıştır. Yapılan birçok çalışmada öğrencilerin akademik kariyer odaklı lisansüstü eğitimi aldıkları görülmekteyken Gemme ve Gingras'ın (2012) çalışmasında akademik kariyer yapma isteğinin altında yatan sebeplere inilmiş ve üniversiteendüstri-hükümet ilişkilerinde aktif rol oynama boyutu ortaya çıkmıştır. Bu çalışmaya göre ise öğrencilerin daha çok iş olanağına sahip olmak ve toplumsal statülerini yükseltmek için lisansüstü eğitim almak istediklerini, bu anlamda gerekli beceri ve donanımla mezun olmayı bekledikleri belirlenmiştir.

Yapılan araştırmalara bakıldığında, lisansüstü eğitim yapma nedenleri bazı çalışmalarla ortaya konmuştur. Fakat daha derinlemesine bilgi toplanması adına öğrencilerin kapsamlı görüşleri alınmamıştır. Lisansüstü eğitimin amacına hizmet edebilmesi adına öncelikle öğrencilerin bu eğitimi almak isteme nedenleri ve beklentilerinin karşılanması önemlidir. Çünkü birçok kurumda olduğu gibi çalışanların ya da öğrencilerin beklentilerinin karşılanmaması, bu kişilerin ilgili eğitim kurumunun amaçlarını tam anlamıyla bilmemeleri gibi nedenler çeşitli sorunlara neden olmaktadır. Bu gibi detayların irdelenmesi önemli görülmektedir. 


\section{Lisansüstü Eğitim}

Lisans eğitimi lisansüstü eğitimden oldukça farklıdır. Çünkü lisans düzeyindeki öğrenciler alanlarıyla ilgili konulara yüzeysel yaklaşırken, lisansüstü öğrencileri derinlemesine bilgiyle tanışır ve yaşam boyu öğrenme sürecinin bir parçası haline gelir (Rosovsky, 1996).

Lisansüstü eğitim; bireylerin bir alanda derinlemesine çalışmalar yapmasını sağlayan, aynı zamanda da araştırmaları ve çalışmalarıyla bilginin ilerlemesine katkı sağlayacak, toplumun değişme ve yenileşme ihtiyacını karşılayacak, nitelikli ihtisas gücünü yetiştirmeyi amaç edinen bir süreç ve bir eğitim faaliyetidir (Varış, 1972).

Lisansüstü eğitim; yüksek lisans programları (tezsiz, tezli), doktora ve sanatta yeterlilik programlarından oluşmaktadır. Tezsiz yüksek lisans programında öğrencilere mesleki alanlarında derin bilgi kazandırılarak, bu bilgileri nasıl uygulayacağı gösterilirken; tezli yüksek lisans programında öğrencilere bilimsel araştırma yaparak ulaştığı bilgileri değerlendirme ve yorumlama becerisi kazandırılması amaçlanmaktadır (RG-01.07.1996-22683). Doktora programlarının amacı ise; bireylere bağımsız araştırma becerisi kazandırmak, alanlarında özgün çalışmalar yapabilmesini sağlamak, olaylara daha geniş bir perspektiften bakarak, derinlemesine inceleme ve yorumlama yeteneği kazandırmaktır (Tosun, 1997).

Türkiye'de, Lisansüstü Eğitim-Öğretim Yönetmeliğine göre, bir yüksek lisans öğrencisinin tez hazırlarken bilimsel araştırma yaparak bilgiye ulaşması, ulaşılan bilgiyi değerlendirmesi ve yorumlama yeteneğini kazanması amaçlanmaktadır. Doktora öğrencisinden ise bağımsız araştırma yapabilme yeteneği kazanarak yeni bir bilimsel yöntem geliştirmesi ya da bilineni rahatlıkla uygulaması beklenir (YOK, 2012).

Kişi mesleği ne olursa olsun toplumda üstüne aldığı görevi daha etkili bir şekilde yerine getirmek, genel kültürünü ve bilgisini artırmak amacıyla daha çok öğrenmeye ihtiyaç duyar. Bu bağlamda enformasyon ve iletişim teknolojisindeki hızla artan yenilikler yaşam boyu öğrenmeyi bir bağımlılık haline getirmiştir (Türker, 1997, s.21). Toplumsal sistemlerin nitelikli insan gücüne olan ihtiyac bireylerin daha fazla ve daha nitelikli eğitim almalarını gerekli kılmıştır (Sağlam, 2007). Ayrıca günümüzde lisansüstü eğitimin kamu ve özel sektör alanlarında istihdam sağlamanın bir önkoşulu haline gelmesi, lisansüstü eğitim almaya yönelik talepleri de artırmıştır (Karaman ve Bakırcı, 2010).

Lisansüstü eğitim akademik yaşamın bir dönüm noktası ve başlangıcıdır (Smith, 2013). Öğrenciler bu süreçte, akademik açıdan pek çok deneyime sahip olmaktadır. Öğrencilerin lisansüstü eğitim sürecinde kazandığı her türlü deneyim onları hayal ettikleri akademik kariyere hazırlamaktadır (Gemme, 2005; Golde ve Dore, 2001).

Lisansüstü eğitimin işlevleri; eğitim-öğretim, araştırma-geliştirme, psiko-sosyal ve sosyo-ekonomik boyutlar olmak üzere toplam dört boyutta ele alınmaktadır. Eğitim-öğretim boyutu ile belirli amaçlar doğrultusunda kişiye bilgi, beceri ve tutum kazandırmak amaçlanmaktadır. Kişinin alanla ilgili yeni bilgileri öğrenme isteği ve kendini geliştirme isteği gibi etmenler bu kapsamda yer almaktadır. Araştırma-geliştirme boyutu kişinin akademik becerilerini geliştirip araştırma yapma yeteneğini arttırmaya yönelik unsurlar yer almaktadır. Kişilerin tez sürecinin rahat geçirebilmeleri için gerekli becerileri kazanma istekleri bu boyutta ele alınmaktadır. Psiko-sosyal boyutta kişinin çevreye uyumunun sağlanması, kendine güveninin artması gibi etmenler yer almaktadır. Sosyo-ekonomik boyutta ise kişinin yaşamını sürdürebilmesi için iş ve meslek kazanımına yönelik etmenler yer almaktadır (Erkılıç, 2007).

\section{YÖNTEM}

\section{Araştırmanın Deseni}

$\mathrm{Bu}$ araştırma lisansüstü öğrencilerinin lisansüstü eğitim alma nedenleri ve lisansüstü eğitimden beklentilerine yönelik düşüncelerini ve görüşlerini belirlemek amacıyla nitel araştırma paradigmasına göre yapılandırılmıştır. Nitel araştırmada araştırmacılar, bireylerin deneyimlerini nasıl yorumladıklarını ve anlamlandırdıklarını, kelimeleri ve anlamları nasıl inşa ettiklerini anlamaya çalışır (Merriam, 2014). Bu çalışmada, araştırmacının durum üzerinde çok az kontrolünün olduğu, gerçek yaşam bağlamında güncel bir olguya odaklanarak nasıl ve neden sorularını yönelttiği ve derinlemesine incelemeler yaptığı bir yöntem (Yin, 2009) olan vaka çalışması deseni kullanılmıştır. Araştırmada ele alınan durum, lisansüstü öğrencilerinin lisansüstü eğitimi alma nedenlerine ve lisansüstü eğitimden beklentilerine 
ilişkin görüşleridir. Araştırmada bu durumun alt analiz birimlerini doktora programları ve yüksek lisans programları oluşturmaktadır.

\section{Çalışma Grubu}

Araştırma, 2011-2012 öğretim yılı bahar döneminde Eskişehir Osmangazi Üniversitesi Eğitim Bilimleri Enstitüsü'nde öğrenim gören 10 lisansüstü öğrencisi üzerinde yapılmıştır. Bu lisansüstü öğrencileri nitel araştırmalarla özdeşleşmiş amaçlı örnekleme yöntemlerinden maksimum çeşitlilik örnekleme tekniğiyle belirlenmiştir. Maksimum çeşitlilik örnekleme, araştırmacının seçtiği örnek olay için hiçbir çeşitlilik kalmayıncaya kadar örnek olay bulmaya çalıştığı bir yöntemdir (Neuman, 2007). Buna göre çalışma grubu belirlenirken lisansüstü öğrencilerinin öğrenim görmekte oldukları program ve lisansüstü dereceleri dikkate alınmıştır. Çalışmaya katılan lisansüstü öğrencilerinin 4'ü doktora öğrencisi, 6'sı yüksek lisans öğrencisidir. Çalışma grubunun özellikleri Tablo 1'de sunulmuştur.

Tablo 1. Çalışma Grubu ve Özellikleri

\begin{tabular}{lllll}
\hline Öğrenci & Program & Cinsiyet & Bölümü & Mezun Olduğu Bölüm \\
\hline EYTPE-1 & Doktora & Erkek & Eğitim Yönetimi, Teftişi, Planlamas1 ve Ekonomisi & Fen Bilgisi Öğretmenliği \\
EYTPE-2 & Doktora & Erkek & Eğitim Yönetimi, Teftişi, Planlamas1 ve Ekonomisi & Fizik Öğretmenliği \\
EPÖ-1 & Doktora & Erkek & Eğitim Programları ve Öğretim & Matematik Öğretmenliği \\
EPÖ-2 & Doktora & Kadın & Eğitim Programları ve Ögretim & Sinıf Öğretmenliği \\
EYTPE-3 & Yüksek Lisans & Kadın & Eğitim Yönetimi, Teftişi, Planlamas1 ve Ekonomisi & İngilizce Öğretmenliği \\
EPÖ-3 & Yüksek Lisans & Kadın & Eğitim Programları ve Öğretim & İngilizce Öğretmenliği \\
EPÖ-4 & Yüksek Lisans & Kadın & Eğitim Programlar1 ve Öğretim & İngilizce Öğretmenliği \\
İMÖ-1 & Yüksek Lisans & Erkek & İlköğretim Matematik Öğretmenliği & Matematik Öğretmenliği \\
IMÖ-2 & Yüksek Lisans & Kadın & İlköğretim Matematik Öğretmenliği & Matematik Öğretmenliği \\
İÖ-1 & Yüksek Lisans & Kadın & İlköğretim Fen Bilgisi Öğretmenliği & Fen Bilgisi Öğretmenliği \\
\hline
\end{tabular}

\section{Veri Toplama Aracı}

Araştırmada veriler araştırmacı tarafından hazırlanan yapılandırılmış bir görüşme formu ile toplanmıştır. Görüşme formu hazırlanırken; öncelikle konuyla ilgili literatür incelenmiş ve eğitim yönetimi alanından bir öğretim üyesinin görüşü ve önerileri doğrultusunda formun gerekli düzenlemeleri yapılmıştır. Görüşme formu lisansüstü öğrencilerin lisansüstü eğitim alma nedenlerini ve lisansüstü eğitimden beklentilerini belirlemeye yönelik 5 açık uçlu sorudan oluşmaktadır. Görüşmeler lisansüstü öğrencilerle yüz yüze gerçekleştirilmiş olup, ortalama 20 dakika sürmüştür. Görüşme esnasında öğrencilerin de rızası alınarak ses kaydı yapılmış, daha sonra bu kayıtlar yazılı hale getirilmiştir. Yazılı hale getirilen kayıtlar, görüşme yapılan öğrencilerle yeniden görüşülerek, görüşlerinin doğru yansitılıp yansitılmadığına dair onayları alınmıştır.

\section{Verilerin Analizi}

Araştırmada elde edilen verilerin çözümlenmesinde içerik analizi yöntemlerinden kategorisel analiz yöntemi kullanılmıştır. Kategorisel analiz yönteminde; yazılı veya sözlü ifadelerden elde edilen veriler kodlanarak sistematik bir şekilde sınıflandırılır ve veriler arasındaki ilişkiler ortaya çıkarılarak anlam oluşturulmaya çalışılır (Marvasti, 2004). Bu bağlamda ses kaydı yapılarak elde edilen veriler yazılı hale getirilmiştir. Sonra yazılı veriler kodlanarak, anlam benzerliğine göre alt temalar altında birleştirilmiş, daha sonra oluşturulan temalar ana temalar altında toplanmıştır. Son olarak verilerden yola çıkarak oluşturulan temalar arasındaki ilişkiler belirlenerek açıklanmaya çalışılmıştır. Ayrıca veri analizinin güvenirliğini sağlamak için araştırmacı dışında veriler bir başka eğitim uzmanı tarafından da kodlanmıştır. Her iki araştırmacının yaptığı kodlamalar üzerinde Güvenirlik = Görüş Birliği / Görüş Birliği + Görüş Ayrılığı X 100 formülü (Miles ve Huberman' dan aktaran Merriam, 2014) uygulanmıştır. Yapılan iki kodlamanın uyuşum yüzdesi \% 77 olarak hesaplanmıştır. Uyuşum yüzdesinin \% 70 veya üzerinde olması veri analizinin güvenirliği açısından yeterli görülmektedir.

\section{Geçerlik ve Güvenirlik}

Nitel araştırmada geçerlik; araştırma sonuçlarının, ne düzeyde doğru olduğu ve araştırmanın genel çerçevesine uygunluğuyla ilgilidir; güvenirlik ise araştırma sonuçlarının önyargı ve hatalardan arınık olması, aynı zamanda da sonuçların farklı araştırmacılar tarafından tekrar edilebilmesi anlamına gelmektedir (Yin, 2009; McMillan, 2004). Bu bağlamda araştırmanın geçerliğini ve güvenirliğini artırmak için şu önlemler alınmıştır; 
a. Araştırmanın iç geçerliğini artırmak amacıyla görüşme sonrası katılımcıların ifadeleri yazılı hale getirilmiş, daha sonra bu metinlerin katılımcıların gözden geçirmeleri sağlanmış ve ifadelerin doğru yansıtılıp yansıtılmadığına dair onayları alınmıştır. Ayrıca görüşme esnasında katılımcılara, görüşlerinin yalnızca bu araştırmada kullanılacağını ve kimliklerinin ifşa edilmeyeceğine dair güvence verilerek, görüşlerini samimi bir şekilde ifade etmeleri sağlanmaya çalışılmıştır. Bu doğrultuda görüşme sürecinde elde edilen verilerin gerçek durumu yansıtması amaçlanmıştır. Ayrıca içerik analizi yapılırken veriler birçok kez gözden geçirilmiş, verilerden yola çıkılarak oluşturulan alt temaların aralarındaki ilişkiler ve ana temaların birbiriyle ilişkisi kontrol edilmiş ve bir bütünlük sağlanmaya çalışılmıştır.

b. Araştırmanın dış geçerliğini artırmak amacıyla araştırma süreci ayrıntılı olarak açıklanmaya çalışılmıştır.

c. Araştırmanın iç güvenirliğini artırmak için içerik analizi sonucunda ortaya çıkan bulgular yorum yapılmadan aktarılmaya çalışılmıştır.

d. Araştırmanın dış güvenirliğini artırmak amacıyla araştırma sürecinde yapılanlar ayrıntılı olarak sunulmuştur. Elde edilen veriler ve kodlamalar tekrar incelenebilecek şekilde araştırmacı tarafindan muhafaza edilmektedir.

\section{BULGULAR}

$\mathrm{Bu}$ bölümde lisansüstü öğrencilerinin görüşleri ana temalar ve alt temalar eşliğinde sirasıyla sunulmaktadir.

\section{Lisansüstü eğitimin işlevi}

Lisansüstü öğrencilerinin, lisansüstü eğitime yönelik genel algılarının ve genel düşüncelerinin belirlenmesi için yapılan görüşmeler sonrasında bu konuya ilişkin altı tema belirlenmiştir (Tablo 2). Buna göre öğrenciler lisansüstü eğitimin; bilimsel çalışmalara yönlendirdiğini, nitelikli insan yetiştirdiğini, farklı bakış açıları kazandırdığını, araştırma yapma becerisini geliştirdiğini, düşünme ve yorumlama becerisini geliştirdiğini, bir alanda uzmanlaşmayı sağladığını düşünmektedirler.

Tablo 2. Lisansüstü Öğrencilerinin Lisansüstü Eğitimin İşlevine İlişkin Görüşleri

\begin{tabular}{llccc}
\hline \multirow{2}{*}{ Ana tema } & \multicolumn{1}{c}{ Alt Temalar } & Doktora & Yüksek Lisans & Toplam \\
& & $n$ & $n$ & $n$ \\
\hline & Bilimsel çalışmalara yönlendirme & 2 & 5 & 7 \\
& Nitelikli insan yetiştirme & 3 & 3 & 6 \\
Lisansüstü & Farklı bakış açları kazandırma & 3 & 2 & 5 \\
Eğitimin İşlevi & Araştırma yapma becerisini geliştirme & 1 & 3 & 4 \\
& Düşünme ve yorumlama becerilerini geliştirme & 2 & 1 & 3 \\
& Bir alanda uzmanlaşmayı sağlama & 1 & 2 & 3 \\
\hline
\end{tabular}

Tablo 2'de görüldüğü üzere öğrencilerin çoğu $(n=7)$ lisansüstü eğitimin öncelikli işlevinin bireyleri alanlarıyla ilgili bilimsel çalışmalara yönlendirmek olduğunu belirtmiştir. Bu öğrenciler, bilimsel çalışmaları akademik hayata atılmak için önemli bir deneyim olarak görmektedir. Ayrıca altı öğrenci lisansüstü eğitimin işlevinin kendini sürekli geliştiren nitelikli bireyler yetiştirmek olduğunu vurgularken, beş öğrencinin görüşü de bireylerin olaylara karşı farklı bakış açıları kazanmasını sağlamak olduğu yönündedir. Yine dört öğrenci lisansüstü eğitimin araştırma yapma becerilerini geliştirme, üç öğrenci düşünme ve yorumlama becerilerini geliştirme, üç öğrenci de bir alanda derinlemesine bilgilere ulaşarak uzmanlaşmayı sağlama gibi işlevlerinin olduğunu vurgulamıştır.

Öğrenciler, lisansüstü eğitimin işlevine yönelik görüşlerini bildirirken kendileri açısından önemli ve öncelikli olan işlevleri belirtmişlerdir. Örneğin;

Lisansüstü eğitim kişinin ufkunu açmada yeni fikirleri tanıma noktasında önemli diye düşünüyorum. Çünkü genel bilgilerin verildiği lisans eğitimi ile ciddi bir farkı var ve genellikle tartışma biçiminde geçen dersler sonucunda kişinin düşünme ve yorumlama becerileri, araş̧tırma yeteneği ciddi biçimde gelişebiliyor $(E P \ddot{O}-1)$.

Lisans eğitiminden çok da farklı olduğunu düşünmüyorum. Tek farkı bilimsel çalışmalara yönlendirmesi. Bu sayede bilimsel çalışmaları inceleyebilmemi sağllyor. Dünyada alanımla ilgili gelişmelerden haberdar olabiliyorum (IMÖ-1). 
Öğrencilerin çoğunun lisansüstü eğitimin işleviyle ilgili görüşleri bir öneri niteliğindedir ve lisansüstü eğitimin işlevinin neler olduğundan ziyade nasıl olması gerektiği yönünde görüşlerini bildirmişlerdir. Lisansüstü eğitim toplumun ihtiyaç duyduğu nitelikli insanların yetişstirilmesinde önemli bir basamak. Bu amaçla akademik hayata atılarak bilim insanı olmak isteyen kişilere daha nitelikli ve uygulama ağırlıklı bilimsel çalışmalar yaptırllmall, alanlarıla ilgili deneyimler kazandırılmalı (EYTPE-1).

Bireyi daha çok araştırmaya yönlendirmelidir. Hazır bilgiden çok keşfetmeye özendirmelidir. Bireyi yaratıcılı̆̆ aşıllamalı, bilimsel bilginin tek ve değişmez olduğundan ziyade, bilginin sürekliliği ögretilmelidir (EYTPE-3).

Sonuç olarak öğrencilerin lisansüstü eğitimin işleviyle ilgili görüşleri; bireyleri bilimsel çalışmalara yönlendirme, nitelikli bireyler yetiştirme ve farklı bakış açıları kazandırma yönünde ağırlıklı olduğu görülmektedir.

\section{Lisansüstü eğitim almada etkileyici olan faktörler}

Öğrencilere; lisansüstü eğitimi talep etmelerinde hangi faktörlerin belirleyici olduğu sorulmuş ve görüşler üç tema altında toplanmıştır. Buna göre öğrencilerin; kendilerini geliştirme arzuları, geleceğe ilişkin hedeflerini gerçekleştirme ve araştırmayı seviyor olmaları lisansüstü eğitimi almalarında etkili olmuştur.

Tablo 3’te görüldüğü üzere çalışma grubundaki yüksek lisans öğrencilerinin tümü ve bir doktora öğrencisi $(n=7)$ kendilerini geliştirmek istedikleri için lisansüstü eğitim almak istediklerini belirtmiştir. Bu görüşteki öğrencilerin bazılarının ifadesi şöyledir;

Yerimde duran statik biri değilim. Gerek günlük yaşamımda olsun gerekse mesleki hayatımda kendimi sürekli yenilemek ve geliştirmek istiyordum. Bunun beni psikolojik açıdan rahatlatacağını düşündüm (EPÖ-4).

Öğrenme bir süreçtir ve hayatımızın sonuna kadar da böyle devam eder. Ben aslında sadece kendimi biraz daha geliştirmek için eğitimime devam etmek istedim. Bu nedenle yüksek lisans yapmaya karar verdim (EYTPE-3).

Ayrıca altı öğrenci lisansüstü eğitimi talep etmede geleceğe dair kariyer hedeflerinin ve ideallerinin peşinden gitme isteğinin etkileyici olduğu yönünde görüş belirtmiştir. Bu görüşe yönelik öğrencilerin bazı ifadeleri şöyledir;

Bunu önceden tasarladı̆̆ımı söyleyebilirim. Hatta bölümümü bile az çok kafamda tasarlamıştım. Bu yüzden bu eğitimi talep etmemdeki tek faktör ileride kendimi görmek istediğim yer yani hedeflerim ideallerim ile alakalıdır (EPÖ-1).

Gelecekte akademik kariyer yapmak istiyorum. Bu amaçla geleceğe dönük planlarım lisansüstü eğitimi talep etmemde etkileyici oldu (IMÖ-1).

Araştırmayı ve öğrenmeyi sevdiği için lisansüstü eğitimi talep ettiklerini belirten beşöğrenciden ikisinin ifadesi de şu şekildedir;

Lisansüstü eğitimi araştırmayl ve ögrenmeyi sevdiğim için istedim (EPÖ-2).

Benim kendi lisans eğitimimde kitap okumayı ve araştırmayı seviyordum. Araş̧tırmacı bir kimliğimin olduğu söylenebilir. Araştırmayı ve ögrenmeyi sevmemde lisansüstü eğitimi talep etmemde etkileyici oldu diyebilirim (EPÖ-4).

Öğrencilerin belirttiği görüşler doğrultusunda çoğunun lisansüstü eğitimi talep etmesinde kendilerini geliştirme isteği, geleceğe ilişkin hedefleri, ayrıca araştırmayı ve öğrenmeyi sevmeleri gibi faktörlerin önemli bir etkisinin olduğu görülmektedir.

Tablo 3. Lisansüstü Öğrencilerinin Lisansüstü Eğitim Almalarında Etkileyici Olan Faktörlere İlişkin Görüşleri

\begin{tabular}{llccc}
\hline \multirow{2}{*}{ Ana tema } & \multicolumn{1}{c}{ Alt Temalar } & Doktora & Yüksek Lisans & Toplam \\
& & $n$ & $n$ & $n$ \\
\hline \multirow{3}{*}{ Faktörler } & Kendimi geliştirme isteğim & 1 & 6 & 7 \\
& Geleceğe ilişkin hedeflerim ve ideallerim & 2 & 4 & 6 \\
& Araştırmayı ve öğrenmeyi seviyor olmam & 3 & 2 & 5 \\
\hline
\end{tabular}

\section{Gelecekle ilgili hedeflerinde lisansüstü eğitimin yeri}

Tablo 4'te gösterildiği gibi, lisansüstü öğrencilerinin gelecekle ilgili hedeflerinde aldıkları lisansüstü eğitimin yerine ilişkin görüşlerine bakıldığında üç tema ortaya çıkmıştır. Bunlar; akademik kariyer için ilk basamak olması, statü kazanmak için önemi bir adım olması ve özelde istihdam edebilmeyi sağlaması 
şeklindedir. Öğrencilerin büyük bir çoğunluğu $(n=7)$; akademisyen olma yolunda önemli bir basamak olduğu yönündedir. İki öğrenci aldıkları lisansüstü eğitimin şu anki mesleklerinde iyi bir statü kazandıracağı görüşündeyken yalnızca bir öğrenci özel sektörde istihdam edilmesini sağlayacağı yönünde görüş belirtmiştir.

Lisansüstü eğitimin akademisyen olabilmek için bir basamak olduğunu belirten öğrencilerin bazılarının ifadesi şu şekildedir;

Lisansüstü eğitim kendimi geliştirmeme, tanımama, eleştirmeme imkân verdi. Ileride iyi bir akademisyen olmayı istiyorum ve lisansüstü eğitimin ileride bana önemli yarar să̆layacă̆ın düşünüyorum (EPÖ-2).

Akademisyen olabilmem için ön şart. Bakış açımı genişletebilir. Dünyada bölümümle ilgili neler olduğundan haberdar olabilirim (IMÖ-1).

Akademisyen olmayı düşündügüm için lisansüstü eğitimde kendimi yetiştirmem çok önemli. Bilimsel alan ve entelektüel olarak beni geliştireceğini, hayata yeni bir bakış açısı getirmemi sağlayacak (EYTPE-1).

İki öğrenci ise lisansüstü eğitimin şimdiki mesleklerinde iyi bir statü kazanmayı sağlayacağını ifade etmektedir. Bu konuda bir örnek ifade şu şekildedir;

Çalıştığım kurumda daha etkili bir pozisyona kavuşmamı sağlayabilir. Kuruma daha etkili katkida bulunuyorum. Yenilikleri anlamlandırıp amaçlarını kestirebiliyorum ve arkadaşlarımla paylaşıyorum (EYTPE-2).

Çalışma grubundan yalnızca bir öğrenci aldığı lisansüstü eğitimin özelde istihdam edilmesinde faydalı olacağını belirterek, görüşünü şu şekilde ifade etmiştir;

Illerde özel sektörde ögretmenlik yapmak istiyorum. Yüksek lisans eğitiminin buna katkısı olacă̆ını düşünüyorum. Amacım yüksek lisans yaparak akademisyen olmak değil, ögrencilere daha donanımlı bir şekilde bilgi vermek (IFÖ).

Tablo 4'te de görüldüğü üzere öğrencilerin büyük bir çoğunluğu akademisyen olma yolunda lisansüstü eğitimin gerekli ve katkı sağlayıcı olduğu görüşünde yoğunlaşmıştır.

Tablo 4. Lisansüstü Öğrencilerinin Gelecekle İlgili Hedeflerinde Lisansüstü Eğitimin Yerine İlișkin Görüşleri

\begin{tabular}{|c|c|c|c|c|}
\hline Ana tema & Alt Temalar & $\begin{array}{c}\text { Doktora } \\
n\end{array}$ & $\begin{array}{l}\text { Yüksek Lisans } \\
n\end{array}$ & $\begin{array}{c}\text { Toplam } \\
n\end{array}$ \\
\hline \multirow{3}{*}{ Lisansüstü Eğitim } & Akademik kariyerim için ilk basamak & 3 & 4 & 7 \\
\hline & $\begin{array}{l}\text { Şu anki mesleğimde iyi bir statü } \\
\text { kazanmam için önemli bir adım }\end{array}$ & 1 & 1 & 2 \\
\hline & Özelde istihdam edilmeme katkı sağlayacak & - & 1 & 1 \\
\hline
\end{tabular}

\section{Öğrenim Görmekte Olduğu Program}

Öğrencilerin öğrenim görmekte oldukları programla ilgili görüşleri; toplumsal konuları yansıtan, ilgi duyulan, mesleki gelişimi sağlayan ve beklenen katkıyı sağlamayan olmak üzere dört temada toplanmıştır. Tablo 5'te görüldüğg̈ gibi yedi öğrenci öğrenim görmekte programın sosyal bir boyutunun olduğu görüşündedir. Bu konuda bazı öğrenciler görüşlerini şöyle ifade etmiştir;

Okuduğum bazı kitaplar ve hocalarımın deneyimlerinden ve bize aktardıklarından çıkarımlar yaparak özel hayatım ve çalışma hayatımdaki vizyonumu gelişstirdi. Ayrıca hayatın tamamen içinde olan konuları tartışmak bana keyif veriyor (EYTPE-3).

Türkiye'de olan eğitim aksaklıkların temelden ele alabilecek insanları yetiştirecek bir bölüm. Dolayısılla çok önemsiyorum bunu. Ë̆itim denince ne yapmak gerekiyorsa nasıl müdahale etmek gerekiyorsa bu programdan çıkacağına inanıyorum (EPÖ-3).

Öğrenim gördükleri programa ilişkin dört öğrencinin görüşü bölümlerine ilgi duydukları yönündedir. Ayrıca iki öğrenci de programlarının mesleki gelişimine katkı sağlayacağını ifade etmiştir. Bu konudaki ifadelerden bir örnek şöyledir;

Bölümüme çok gönüllü olarak geldim ve ilgi duyduğum bir bölümdü. Çünkü işin biraz daha sosyal boyutuna inmek istedim. Bence bütün her şeyin temeli eğitim programlarl ve öğretim ve bana çok yararı oldu. Öğretmenlik hayatıma katkısı olacağını düşünüyorum (EPÖ-4).

Bir öğrenci de öğrenim görmekte olduğu programın beklentisi yönünde bir katkı sağlamadığını belirtmiş ve şöyle ifade etmiştir;

Umduğum kadar bana katkısı olmadı. Alanımla ilgili daha çok bilgi sahibi olacă̆ımı düşünüyordum. Bu yüzden özellikle lisanstaki alanımla ilgili bir yüksek lisans bölümünü tercih etmiştim (IFFÖ-1). 
Sonuç itibariyle öğrencilerin çoğu öğrenim gördükleri bölümle ilgi düşünceleri, programlarının sosyal boyutunun olduğu yönündedir.

Tablo 5. Lisansüstü Öğrencilerinin Öğrenim Görmekte Olduğu Programa İlişkin Görüşleri

\begin{tabular}{llccc}
\hline \multirow{2}{*}{ Ana tema } & Alt Temalar & Doktora & Yüksek Lisans & Toplam \\
n & n & n \\
\hline \multirow{4}{*}{ Lisansüstü Program } & Toplumsal konuların ele alınabildiği bir program & 3 & 4 & 7 \\
& İlgi duyduğum bir bölüm & 2 & 2 & 4 \\
& Mesleki gelişimime katkı sağlayıcı yönde & 1 & 1 & 2 \\
& Beklediğim kadar katkısı olmadı & - & 1 & 1 \\
\hline
\end{tabular}

\section{Lisansüstü Eğitimden Beklentileri}

Lisansüstü eğitim alan öğrencilerin bu eğitimden beklentileri incelendiğinde; alanlarında yetkin ve etkili biri olma, prestijli bir yaşama sahip olma ve kendini geliştirme imkanı bulma yönünde üç tema ortaya çıkmıştır. (Tablo 6)

Tablo 6. Lisansüstü Öğrencilerinin Lisansüstü Eğitimden Beklentilerine İlişkin Görüşleri

\begin{tabular}{clccc}
\hline \multirow{2}{*}{ Ana tema } & \multicolumn{1}{c}{ Alt Temalar } & Doktora & Yüksek Lisans & Toplam \\
& & $n$ & $n$ & $n$ \\
\hline \multirow{2}{*}{ Beklentiler } & Alanımda yetkin ve etkili biri olmamı sağlaması & 4 & 2 & 6 \\
& Prestijli bir yaşam & 1 & 4 & 5 \\
& Kendimi geliştirmeme imkân sağlaması & - & 3 & 3 \\
\hline
\end{tabular}

Tablo 6'da görüldüğü üzere çalışma grubundaki bütün doktora öğrencilerinin $(n=4)$ ve yüksek lisanstan da iki öğrencinin lisansüstü eğitimden beklentilerine yönelik görüşleri, onları alanlarında daha yetkin ve etkili olmalarını sağlaması yönündedir. Bu konuda bazı öğrenciler görüşlerini şöyle ifade etmiştir;

Lisansüstü eğitimin eğitim ve ilgili alanlarda bilgi ve farkındalı düzeyini artırmasını bekliyorum. Ĕ̈itimim süresince incelediğim programlarda gördügüm eksik ya da yanlışlıkları tamamlayarak bir program geliştirebileceğim, böyle bir uzman grubunda yer alabileceğim düzeyde yetkinliğe ulaşmayı bekliyorum (EPÖ-2).

Mesleki yönden yetkinleşmem için alanım hakkında iyi bir alan bilgisine sahip olmam gerek kanısındayım. Ayrıca yönetim bireylerin kendilerini açıkça ifade etmelerini gerektiren bir alan olduğundan, buna imkân verecek durumlar yaratmasını bekliyorum (EYTPE-3).

Beş lisansüstü öğrencisinin lisansüstü eğitimden beklentilerinin daha prestijli bir yaşam olduğunu ifade etmiştir. Bu görüş̧eki öğrencilerin bazılarının ifadesi şöyledir;

Lisansüstü eğitimden beklentim prestijli bir hayat. Alanımda daha derinlemesine bilgilere sahip olarak nitelikli çalı̧̧malar yapmak istiyorum. Yaptı̆̆ım çalışmalarla alanımda saygınlık kazanmak istiyorum (EYTPE-1).

Ilerde bu alanla ilgili uzmanlı̆̆ımı artırmak, akademik olarak. Daha prestijli bir hayat. Böyle bir beklentim var. Daha prestijli derken ekonomik kaygilardan bahsetmiyorum. Akademik çalışmalar yaparak nitelikli bir yaşam sürmek istiyorum (EPÖ-3).

Son olarak da üç lisansüstü öğrencisi lisansüstü eğitimden beklentilerinin kendilerini geliştirmelerine imkân sağlaması olduğunu ifade etmiştir ve bu görüşteki bir öğrencinin ifadesi şöyledir;

Lisansüstü eğitim beni sadece değiştirmesin. Aynı zamanda geliştirsin. Mesleki ve psikolojik açıdan beni geliştirsin istiyorum. Sinavlar bir şeyler öğretmek için uygulanabilir ancak benim beklentim sadece bir şeyler öğrenmek değil aynı zamanda da kendimi geliştirmektir (EPÖ-4).

Yukarıdaki ifadelerden de anlaşıldığı üzere sonuç olarak öğrencilerin lisansüstü eğitimden beklentileri daha çok alanlarında yetkinleşmek ve aynı zamanda da yaptıkları çalışmalarla etkili olmak ve saygınlık kazanmak olduğu şeklinde yoğunlaşmaktadır.

\section{TARTIŞMA}

$\mathrm{Bu}$ araştırmada amaç, lisansüstü öğrencilerinin lisansüstü eğitim alma nedenleri ve aldıkları bu eğitimden beklentileri; lisansüstü öğrencilerinin görüşleri doğrultusunda belirlemektir.

Yapılan görüşmelerde öğrencilerin lisansüstü eğitimin işleviyle ilgili görüşleri sorulmuştur. $\mathrm{Bu}$ doğrultuda öğrencilerin çoğu, lisansüstü eğitimin işlevinin bireyleri bilimsel çalışmalara yönlendirmek 
olduğunu ifade etmiş̧tir. Aslında bu durum lisansüstü eğitimin işlevinin bilim insanı ve öğretim görevlisi yetiştirmek olduğu görüşünün hâkim olmasından kaynaklandığı söylenebilir. Çünkü üniversitelerin en önemli görevlerinden biri gelişen bilgi çağına ayak uydurmak için bilim üretmek ve bu üretimi gerçekleştirecek bilim insanları yetiştirmektir. $\mathrm{Bu}$ da üniversiteler bünyesinde hayata geçirilen lisansüstü eğitimlerle sağlanmaktadır (Karaman ve Bakırcı, 2010). Nitekim Karakütük ve Özdemir (2011) de lisansüstü öğretim programlarının, üniversitelerin öğretim üyesi gereksinimlerini karşıladıklarını ifade etmişlerdir. Buna göre öğrencilerin lisansüstü eğitim işlevini doğrudan bilim insanı yetiştirmek ve bununla beraber öğretim görevlisi yetiştirmek olarak düşünmeleri beklenen bir durumdur. Yine araştırmaya katılan öğrencilerin çoğu lisansüstü eğitimin işlevinin nitelikli insan yetiştirmek olduğunu belirtmiştir. Buradaki nitelikli insan kavramı, öğrencilerin ifadeleri de dikkate alındığında; öğrencilerine faydalı bir öğretmen, toplumsal sorunlara duyarlı bir araştırmacı, kendini sürekli geliştiren bir birey olarak ele alınabilir. Öğrencilerin genelinin görüşü, lisansüstü eğitimin işlevinin neler olduğundan ziyade nasıl olması gerektiği yönünde ve bir öneri niteliğinde olması da dikkat çekicidir. $\mathrm{Bu}$ durum onların lisansüstü eğitimden beklentilerini de ortaya koymaktadır. Çünkü öğrencilerin çoğu, lisansüstü eğitimden beklentilerinin alanlarında yetkili ve etkin biri olmak olduğunu belirterek, nitelikli insan yetiştirme işlevine vurgu yapmaktadır. Ayrıca öğrenciler lisansüstü eğitimin bireylere farklı bakış açıları kazandırma, araştırma yapma becerilerini geliştirme, düşünme ve yorumlama becerilerini geliştirme gibi işlevlerinin olduğunu ifade etmiştir. Öğrencilerinin lisansüstü eğitimin işlevine yönelik görüşleri, Üniversitelerarası Kurul'un hazırladığı Lisansüstü Eğitim ve Öğretim Yönetmeliği'nde belirtilen işlevlere paralel olduğunu göstermektedir. Bu durumda çalışma grubundaki öğrencilerin çoğunun lisansüstü eğitimi bilinçli tercih ettikleri söylenebilir. Araştırmanın önemli sonuçlarından biri de öğrenciler için lisansüstü eğitimin akademik kariyerleri açısından önemli bir basamak olduğudur. Lisansüstü öğrencilerinin çoğu, özellikle de doktora öğrencileri kendilerini akademik bir pozisyonda hayal eder. Dolayısıyla lisansüstü eğitim, öğrencilerin akademik kariyer hedefleri için ilk ve önemli bir basamaktır. Literatür incelendiğinde yapılan araştırma sonuçları da bu bulguyu destekler niteliktedir ve öğrenciler her ne kadar akademisyenlik dışında farklı kariyer ve meslek edinme olanaklarına sahip olabileceklerini bilseler de akademik kariyer onlar için daha çekici görünmektedir (Gemme ve Gingras, 2012; Gemme, 2005; Golde ve Dore, 2001). Akademik kariyer için öncelikle bir lisansüstü programın başarıyla tamamlanması ve bilimin ilerlemesini sağlayacak nitelikte bilimsel araştırmalar yaparak araştırma sonuçlarının yayınlanması gerekmektedir (Odabaşı, Fırat, İzmirli, Çankaya ve Mısırlı, 2010). Araştırmada öğrencilerin gelecekle ilgili hedeflerinin akademik kariyer yapmak yönünde olması aslında onların lisansüstü eğitimin işlevine yönelik bilimsel çalışmalara yönlendirmek görüşünün beklenti niteliğinde olduğunu kanıtlamaktadır.

Araştırmada öğrencilerin geneli lisansüstü eğitimi talep etmelerinde kendilerini geliştirme isteklerinin önemli etkisinin olduğunu belirtmiştir. Bu konuyla ilgili yapılan önceki araştırma sonuçlarında da benzer bulgular elde edilmiştir (Aslan, 2010; Demirbolat, 2005). Ancak öğrencilerin bu konuyla ilgili görüşleri, lisansüstü eğitimden beklentilerine ilişkin görüşleriyle çelişmektedir. Çünkü öğrencilerin beklentileri kendilerini geliştirmelerinden ziyade alanlarında yetkin ve etkili biri olmak, ayrıca yaptıkları çalışmalar sonucunda saygınlık kazanmak olduğu yönündedir. Öğrencilerin geleceğe ilişkin hedefleri ve idealleri de lisansüstü eğitimi talep etmelerinde etkileyici bir faktördür ve öğrencilerin akademik kariyer beklentileri açısından tutarlıdır. Bireylerin kendilerini geliştirmeleri için akademik kariyer yapma zorunluluğu yoktur; ancak akademik kariyer için kendilerini geliştirmek zorundadırlar. Öğrenciler, kendilerini geliştirme isteğinin bir gereksinim mi yoksa bir zorunluluk mu olduğuna karar vermelidir.

Yine öğrencilerin araştırmayı ve öğrenmeyi sevmeleri, lisansüstü eğitimi talep etmelerinde etkileyici olmuştur. Çünkü araştırma ve lisansüstü eğitim birbirine yakından bağlantılıdır ve bu süreçte öğrencilerin yeni bilgileri keşfetmeleri ve geliş̧irmeleri söz konusudur (Smith, 2013).

Araştırmanın çalışma grubunu oluşturan öğrencilerin çoğunun görüşü, öğrenim görmekte oldukları programa ilişkin sosyal boyutunun olduğu yönündedir. Bu görüşteki öğrenciler, süreçte toplumsal konuların ele alındığını ifade etmiştir. Ancak yalnızca dört öğrenci ilgi duydukları bir bölüm olduğunu belirtmiştir. Aslında öğrencilerin pek çoğu kişisel ilgilerine uyumlu bir alanda çalışmayı tercih eder ve kişisel ilgi, alan seçimini önemli derecede etkilemektedir (Smith, 2013). Bu açıdan bakıldığında öğrencilerin görüşlerinde çelişkiler olduğu açıkça görülmektedir. Yani lisansüstü eğitimin ilgi alanlarına yönelik değil de toplumsal konulara yönelik süregeldiğinin düşünülmesi öğrencilerin hem toplumsal konulara eğilimlerinin az olduğunu, hem de seçtikleri alanı gerçekten ilgilerine yönelik mi yoksa bir 
zorunluluk ya da tercihten dolayı mı olduğu sorusunu akıllara getirmektedir. Bu noktada öğrencilerin bir kısmının puanı ya da bölümün açtığı kontenjan doğrultusunda yani bir zorunlulukla lisansüstü eğitim aldıkları bölümü tercih ettikleri ve dolayısıyla da beklentilerinin karşılanamadığı söylenebilir.

\section{SONUÇ}

Lisansüstü öğrencileri, lisansüstü eğitimin bilimsel çalışmalara yönlendirme, nitelikli bireyler yetiştirme ve farklı bakış açıları kazandırdığını düşünmektedirler. Bu kapsamda bilimsel çalışmalar ile akademik hayata atılımın sağlandığı gibi genel bir sonuç ortaya çıkmıştır.

Lisansüstü öğrencilerinin lisansüstü eğitim almasında; kendini geliştirme isteği, araştırma yapmaktan ve öğrenmekten zevk alma faktörleri etken olmuştur. Lisansüstü eğitime başlayan öğrenciler genel olarak akademisyen olmayı hedeflemektedirler ve bu doğrultuda ilerlemek adına planlar kurmaktadırlar. Lisansüstü eğitimin öğrenciyi sosyalleştirdiği tespit edilmiştir. Akademik anlamda kişiyi geliştirdiği gibi sosyal anlamda da bireye katkı sağladığı ortaya çıkmıştır. Lisansüstü eğitime başlayan öğrencilerin kendilerini geliştirme, alanlarında daha yetkin ve saygın insanlar olma beklentisi içerisinde oldukları sonucuna ulaşılmıştır.

Sonuç olarak lisansüstü öğrencilerinin alanlarında başarılı olabilmeleri ve alanlarına katkı sağlayabilmeleri için öncelikle o alana yatkınlıklarının olması ve alanlarına ilgi duyması gerekmektedir. Öğrencilerin başarılı olmasında sahip oldukları yeteneklerin lisansüstü eğitimde pek bir önemi yoktur. Lisansüstü eğitim özellikle de doktora eğitimi yoğun, uzun ve zor bir süreci kapsamaktadır. Dolayısıyla lisansüstü eğitim almak isteyen bireylerin akademik konularla ilgili çalışma yaparken bundan zevk alması ve çalışmayı bir eğlence olarak görmesi gerekmektedir (Rosovsky, 1996).

Ortaya çıkan sonuçlara bakıldığında; öğrencilerin akademik kariyer yapma isteği ile lisansüstü eğitime başlıyor oldukları görülmektedir. Gerçekten bu işin amacına hizmet edebilmesini sağlamak adına iki önemli öneri sunulabilir. Bunlardan ilki; akademik yaşantının olumlu ve olumsuz özellikleri her yönüyle öğrencilere tanıtılmalı. Bunun için akademik çalışmaların arttırılmasının yanı sıra öğrencilere birebir oryantasyon programları düzenlenerek bu eğitim daha yakından tanıtılabilir. Akademik yaşantıları sergileyen hayat hikayelerinden bu noktada destek alınabilir. Özellikle de doktora eğitimi almak isteyen öğrencilere bu tarz kısa ön tanıtımları yapacak çalışmalar gerçekleştirildikten sonra eğitim hayatına atılmaları sağlanabilir. Gerçekten bu eğitimi almak isteyenle, farklı nedenlerden dolayı bu eğitimi almak isteyen ayırt edilmelidir.

İkincisi ise aynı anda birden farklı bölüme başvurup lisansüstü eğitim almanın önüne geçilmelidir. Böylelikle her öğrenci sadece ilgi duyduğu alanda lisansüstü eğitim yapacak ve bu eğitimden beklentilerini de daha objektif değerlendirebileceklerdir. Aksi durumda öğrenci hem ilgisi olmayan bir alanda yer ediniyor hem de beklentisinin karşılanmadığını ifade ediyor olması yine bir çelişki doğurmaktadır.

Bunların dışında öğretim üyelerinin danışmanlığını yürüttüğü öğrencileri ile akademik gelişimi sağlamaları için daha yakından ilgilenmeleri ve bu hususta daha somut düzenlemelerin yapılması önerilebilir. Öğrenci-danışman işbirliği ile yayınlar yapılması zorunluluğu getirilebilir, danışmanın kendi öğrencilerinin birbirleriyle iletişim halinde olacağ 1 ve danışman kontrolünde yürütülecek proje sayılarının arttırılması adına teşvikler fazlalaştırılabilir.

\section{KAYNAKLAR}

Aslan, C. (2010). Türkçe eğitimi programlarında lisansüstü öğrenim gören öğrencilerin akademik özyeterliklerine ilişkin görüşleri. Mehmet Akif Ersoy Üniversitesi Eğitim Fakültesi Dergisi, 19, 87-115.

Demirbolat, A. O. (2005). Yüksek lisans öğrencilerinin programdan ve öğretim elemanlarından beklentileri. Türk Ĕgitim Bilimleri Dergisi, 3, 47-64.

Golde, C. M., \& Dore, T. M. (2001). At cross Purposes: What the experiences of today's doctoral students reveal about doctoral education. (ERIC Document Reproduction Service No. ED450628).

Erkılıç, T. A. (2007). Öğretmen adaylarının lisansüstü eğitim isteklerini etkileyen etmenler (Eskişehir örneği). Girne Amerikan University Journal of Social \& Applied Sciences. 3(5), 46-72.

Gemme, B. (2005). The changing career of doctoral students. (ERIC Document Reproduction Service No. ED489889).

Gemme, B., \& Gingras, Y. (2012). Academic careers for graduate students: a strong attractor in a changed environment. Higher Education, 63(6), 667-683. 
Karaman, S., \& Bakırcı, F. (2010). Türkiye'de lisansüstü eğitim: sorunlar ve çözüm önerileri. Sosyal Bilimler Araştırmaları Dergisi, 2, 94-114.

Karakütük, K. (2001). Öğretim Üyesi ve Bilim İnsanı Yetiştirme: Lisansüstü Öğretimin Planlanması. Ankara: Anı Yayıncilik.

Karakütük, K., \& Özdemir, Y. (2011). Bilim insanı yetiştirme projesi (BİYEP) ve öğretim üyesi yetiştirme programının (ÖYP) değerlendirilmesi. Eğitim ve Bilim, 36(161), 26-38.

Karayalçın, Y. (1988). Lisansüstü Ĕ̆itim Yükseköğretimde Değişmeler. Ankara: Türk Eğitim Derneği Yay.

Köksalan, B. (1999). Üniversite Öğrencilerinin Meslek Seçimini Etkileyen Faktörler, (Doktora tezi). Malatya: İnönü Üniversitesi Eğitim Fakültesi.

Marvasti, A. B. (2004). Qualitative Research in Sociology. London: SAGE Publication.

McMillan, J. H. (2004). Educational research: Fundamentals For the Consumer. Boston: Pearson / A and B.

MEB. (2010). TALIS Uluslararası Öğretme ve Öğrenme Araştırması Teaching and Learninig International Survey Türkiye Ulusal Raporu, MEB Dış İlişkiler Genel Müdürlüğü.

Merriam, S. B. (2014). Qualitative Research: A Quide to Design and Implementation. John Wiley \& Sons.

Neuman, L. W. (2007). Toplumsal Araştırma Yöntemleri: Nitel ve Nicel yaklaşımlar(S. Özge, Çev.). İstanbul: Yayın Odası Yayıncılık.

Odabaşı, H. F., Fırat, M., İzmirli, S., Çankaya, S., \& Mısırlı, Z. A. (2010). Küreselleşen dünyada akademisyen olmak. Anadolu Üniversitesi Sosyal Bilimler Dergisi, 3, 127-142

Resmi Gazete (1996). Lisansüstü Eğitim ve Öğretim Yönetmeliği. Say1: 22683. Tarih: 01.07.1996.

Rosovsky, H. (1996). Üniversite (Bir Dekan Anlatıyor), (çev. Süreyya Ersoy). Ankara: TÜBİTAK.

Sağlam, M. (2007). Lisansüstü Eğitim Modelleri. Anadolu Üniversitesi Eğitim Bilimleri Enstitüsü Lisansüstü Eğitim Sempozyumu: Lisansüstü Eğitimde Sorunlar ve Çözüm Önerileri (17-20 Ekim 2007), 1-12.

Smith, R. V. (2013). Graduate Research: A Guide for Students in the Sciences. Seattle: University of Washington Press.

Tosun, İ. (1997). Bilim Adamı Yetiştirme: Lisansüstü Eğitim. Ankara: TÜBA, Bilimsel Toplantı Serileri 7. (s.7$15)$.

Türker, R. K. (1997). Bilim Adamı Yetiştirme: Dünyada ve Türkiye'de Lisansüstü Eğitim. Ankara: TÜBA, Bilimsel Toplant1 Serileri 7. (s.21-48).

Varış, F. (1972). Türkiye'de Lisansüstü Eğitim: Pozitif Bilimlerin Temel ve Uygulamalı Alanlarında. Ankara: Ankara Üniversitesi Eğitim Fakültesi Yayınları.

Yin, R. K. (2009). Case Study Research: Design and Methods. Los Angeles, Calif.: Sage Publications.

YOK, (2012). Lisansüstü Eğitim Öğretim Yönetmeliği. Erişim tarihi: 07.10.2013, http://www.yok.gov.tr/content/view/417/183/lang,tr/. 